\title{
Cretaceous - Tertiary pre-drift sediments of the Kangerlussuaq area, southern East Greenland
}

\author{
Michael Larsen, Lars Hamberg, Snorre Olaussen \\ and Lars Stemmerik
}

The Cretaceous and Tertiary sedimentary succession around Kangerlussuaq in southern East Greenland is the least known part of the Upper Palaeozoic - Mesozoic rift basins exposed onshore East Greenland. The sediments were briefly described during initial mapping of the region (Wager, 1934, 1947; Wager \& Deer, 1939), and later by Soper et al. (1976), Higgins \& Soper (1981) and Nielsen et al. (1981). Detailed sedimentological studies of a few outcrops were carried out during the late 1980s (Hamberg, 1990; Nørgaard-Pedersen, 1991, 1992), but until now there have been no detailed sedimentological and stratigraphic studies of the region due to logistical difficulties; most of the outcrops are on isolated nunataks.

The main objects of the present study were to supplement the volcanic rifted margin investigations carried out by the Danish Lithosphere Centre (DLC) and to provide an insight into the basin development during Cretaceous to earliest Tertiary rifting. The pre-drift position of the Kangerlussuaq area close to present day petroleum exploration areas makes the sedimentary evolution a potential analogue model for the Cretaceous - earliest Tertiary sedimentary basins in the North Atlantic region (Fig. 1). These basins have acquired new interest as the focus of petroleum exploration has changed from the shallow shelf areas to deeper offshore areas like the Vøring, Møre and FaeroeShetland basins where thick successions of presumed Cretaceous - Tertiary age are preserved (e.g. Hinz et al., 1993; Mitchell et al., 1993).

The work during summer 1995 formed part of a major field campaign in the Kangerlussuaq area under the auspices of DLC (Fig. 2). The presence of two helicopters in the area allowed visits to hitherto undescribed sections and collection of data for sedimentological, stratigraphic and sequence stratigraphic analysis of the entire region has been achieved. The study forms part of a major research project on petroleum systems in the sedimentary basins of North and East Greenland supported by the Danish Research Councils (see Stemmerik et al., this report).

\section{Sedimentary evolution}

Cretaceous and Early Tertiary clastic sediments in the Kangerlussuaq region overlie an irregular erosional sur- face of Precambrian crystalline basement that rises towards the west and north. They crop out below a several kilometre thick cover of Tertiary plateau basalts (Fig. 2), and are locally disturbed by Tertiary intrusions and major sill complexes. Most of the sediments were thus deposited before the onset of volcanism marking the beginning of sea-floor spreading in the Northern Atlantic close to the Paleocene - Eocene boundary at chron 24R. The sedimentary succession reaches $c .1 \mathrm{~km}$ in stratigraphic thickness and belongs to three formations: the Upper Cretaceous Sorgenfri Formation, the Upper Cretaceous - Paleocene Ryberg Formation of the Kangerdlugssuaq Group and the dominantly volcanic Paleocene - Eocene Vandfaldsdalen Formation of the Blosseville Group (Fig. 3) (Soper et al., 1976).

During the 1995 field season a more than $150 \mathrm{~m}$ thick sandstone dominated succession of Early Cretaceous age was recorded below the Sorgenfri Formation. This succession records a change from fluvial and estuarine sandstones to deep marine shales probably related to the initial basin formation in the Late Aptian. The sandy succession

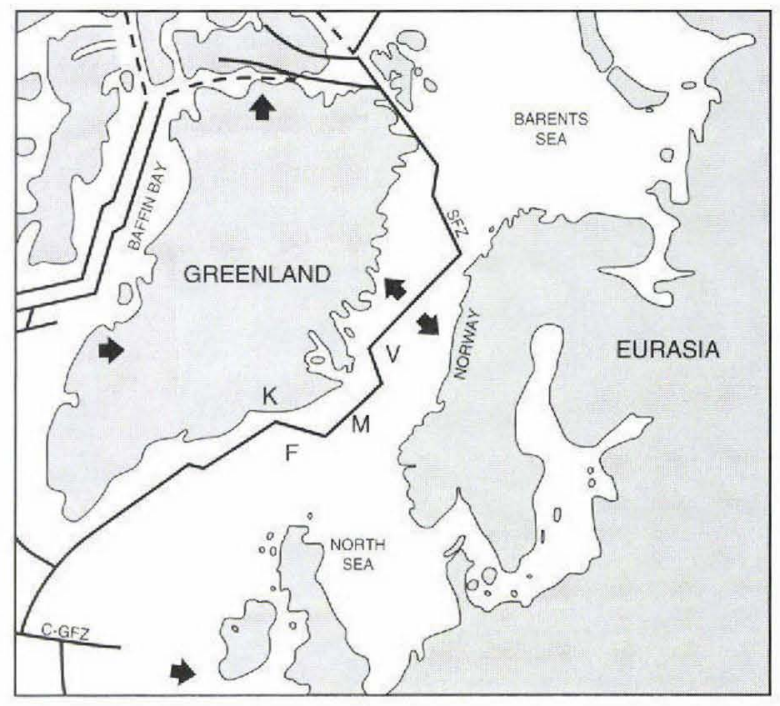

Fig. 1. Pre-drift palaeogeography of the Northern Atlantic showing the break-up during chron 24R near the Paleocene - Eocene boundary. K: Kangerlussuaq, F: Faeroe - Shetland Basin, M: Møre Basin, V: Vøring Basin. Modified from Myhre et al. (1992). 


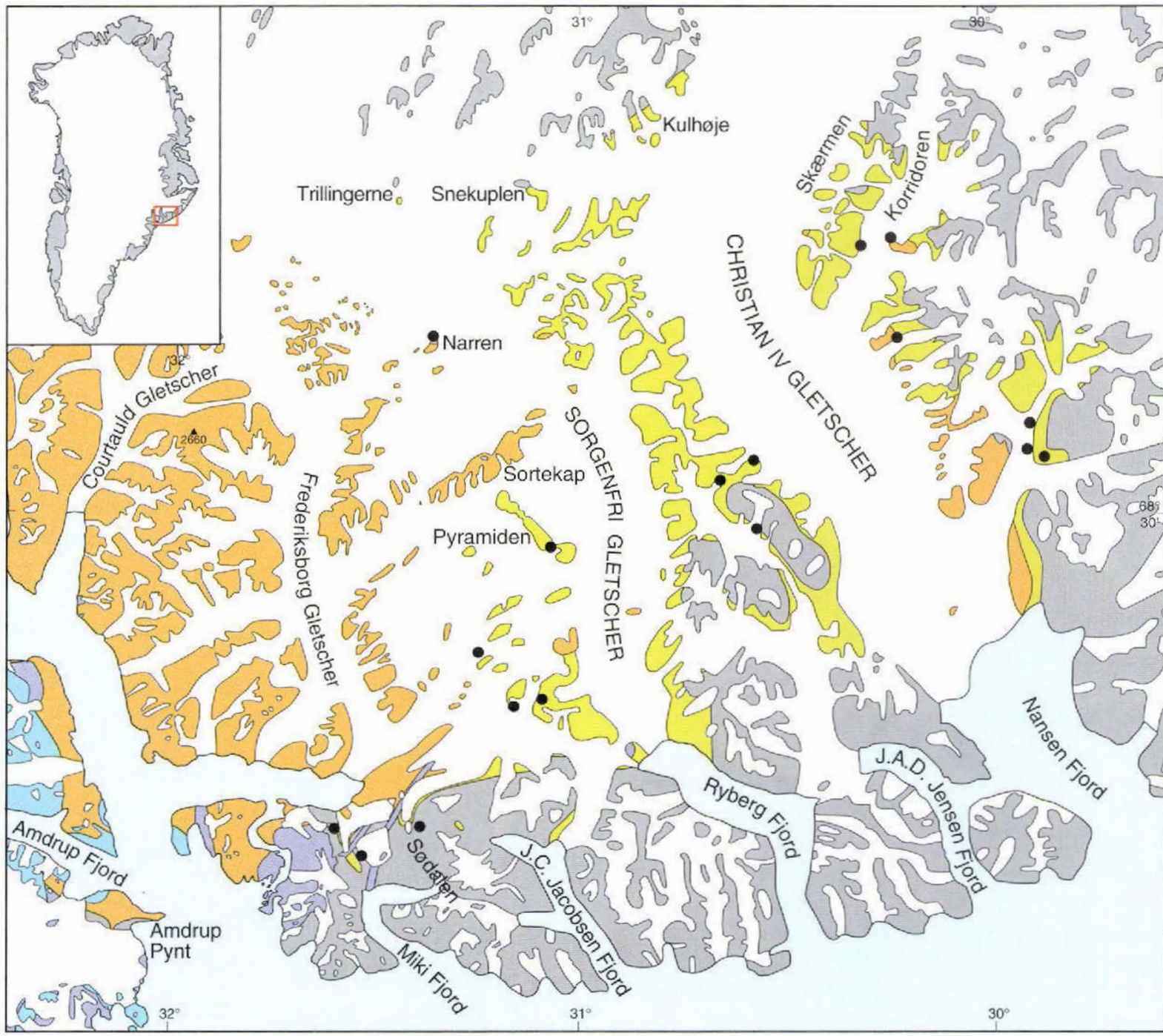

Tertiary felsic plutonic rocks

Tertiary mafic and ultramafic plutonic rocks

Tertiary basaltic rocks

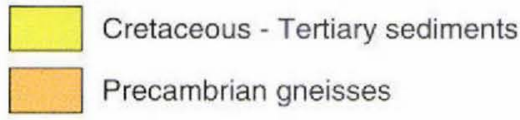

- Section locations

Fig. 2. Geological and location map of the Kangerlussuaq area showing the distribution of the pre-drift sediments. The positions of the main measured sections are indicated.

passes upwards into marine shales and thin turbidites of the Sorgenfri Formation.

The Upper Cretaceous Sorgenfri Formation was originally described from an isolated locality at Ryberg Fjord where it forms a $20 \mathrm{~m}$ thick succession of fossiliferous, grey laminated shale (Soper et al., 1976). Later field work, however, has demonstrated a more extensive distribution and the formation is now believed to form a several hundred metres thick marine shale succession which is exposed at several localities inland e.g. at Pyramiden. The formation boundaries, however, remain ambiguous due to limited outcrops.

The Upper Cretaceous - Paleocene Ryberg Formation reaches $c .200 \mathrm{~m}$ in thickness and consists in the lower part of grey laminated siltstones and black shales alternating with thin turbidite beds of medium- to coarse-grained sandstones. A general coarsening-upward trend and increase in sandstone/mudstone ratio is recorded in the upper part of the measured sections, which show channelised sandstone units $20-35 \mathrm{~m}$ thick and separated by heterolithic shales. 


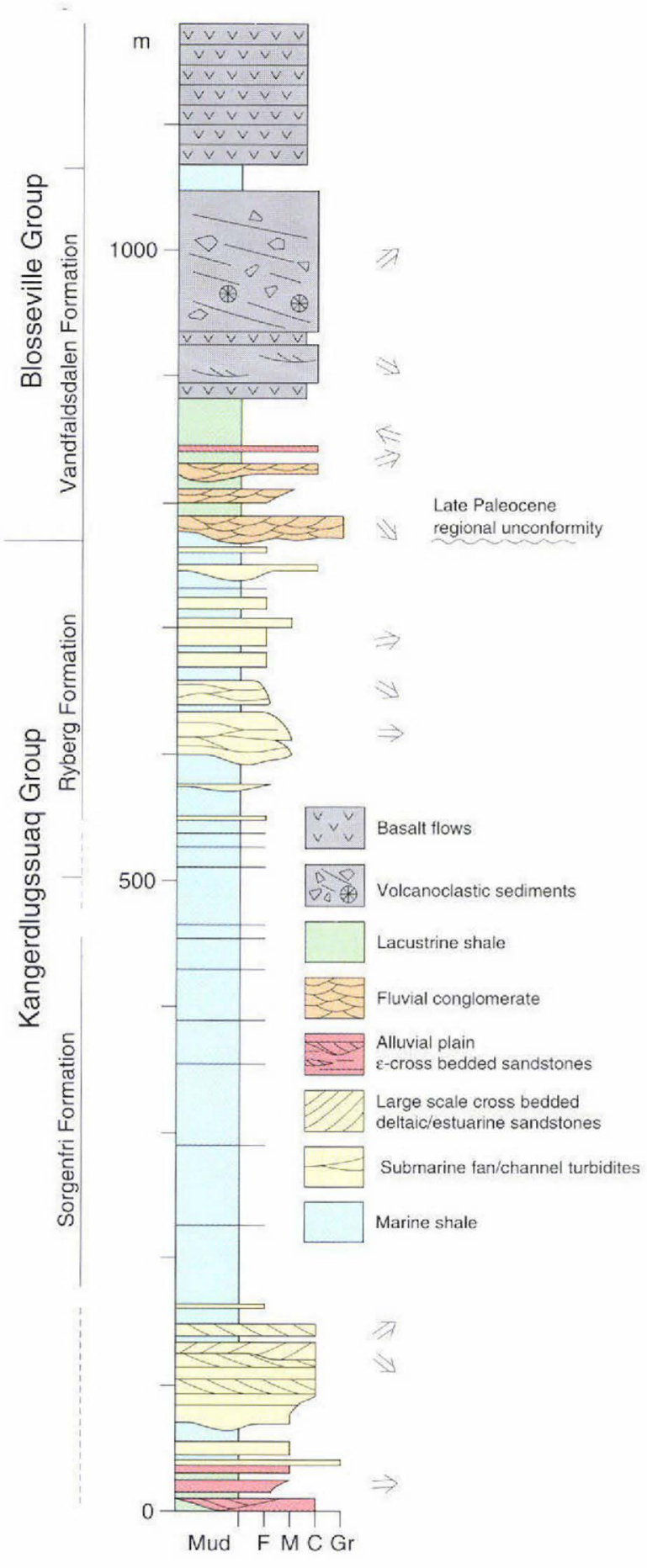

Fig. 3. Composite vertical section through the sedimentary succession in the Kangerlussuaq region. The succession reflects an initial mid-Cretaceous transgression and deepening followed by an overall shallowing during the Late Cretaceous - Early Paleocene. Late Paleocene uplift caused regional erosion and a change from marine to continental deposition. The succession is overlain by lava flows interbedded with volcanic sediments marking the onset of volcanism in the region.
The sandstone units consist of amalgamated turbidite beds showing sediment transport directions towards the southeast and south. The presence of belemnites, marine bivalves and dinoflagellate cysts in the fine-grained portions indicates deposition in a marine basin and the succession is interpreted as laid down in a submarine fan environment. The uppermost tens of metres indicate a rapid shallowingupwards with hummocky cross-stratified sandstones interbedded with marine shales of the lower shoreface.

Continental deposits abruptly overlie the marine sediments and the change in depositional environment seems to mark an Upper Paleocene basin-wide uplift. The most prominent of these deposits is a white, trough cross-bedded, pebbly conglomerate bed, $8-20 \mathrm{~m}$ thick showing transport directions towards the east and south-east (Figs 3,4). The pebbly sandstones are associated with black carbonaceous shales overlying rooted horizons and are interpreted as deposited in a braided river system. The erosional surface is correlated between a number of different sections in the Kangerlussuaq area. The clastic continental sediments are overlain by a thick basalt succession, which towards the east and north-east passes into subaqueously deposited, tuffaceous sediments and hyaloclastites of the Vandfaldsdalen Formation (Soper et al., 1976; Nielsen et al., 1981). Along the north-eastern margin of the basin, the volcanic part of the succession is represented by a continental succession of laminated carbonaceous mudstones that coarsen upwards into channelised sandstones showing palaeocurrent directions towards the west and north-west. These sediments have an upward increasing content of volcanic derived material. Coal beds, of which some are autochthonous with rootlets beneath, become abundant towards the top of the section, indicating deposition in a coastal plain and delta plain environment (Nørgaard-Pedersen, 1991, 1992).

\section{Basin evolution}

Based on preliminary analyses of sedimentological and stratigraphic data collected during the 1995 field season and previous work in the region, the Cretaceous - Early Tertiary evolution of the basin can be summarised as follows.

The sedimentary basin was formed during mid-Cretaceous extension. Basin margin uplift caused erosion of the hinterland and sand dominated sediments were shed into the basin and deposited in estuarine and shallow marine environments. During the Late Aptian the basin was transgressed, possibly in response to an overall rise in relative sea-level. This relative rise in sea-level continued during the Late Cretaceous and the basin developed into a relatively deep marine basin dominated by suspension fall-out and fine-grained sandy turbidites flowing from the north and north-east. Towards the Paleocene sediment influx increased dramatically and a unit of coarse-grained fluvial 


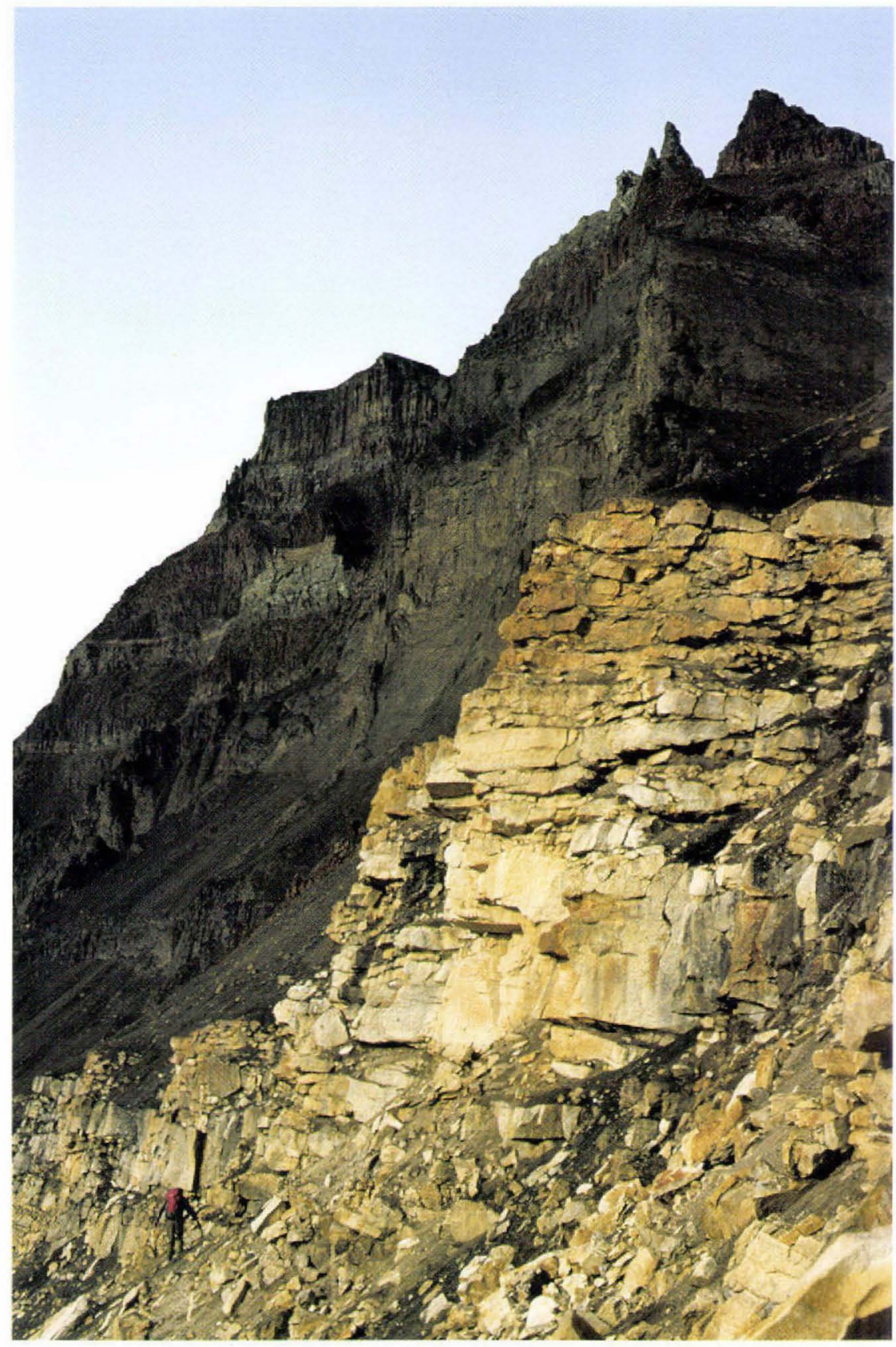

Fig. 4. Fluvial pebbly sandstones forming steep bluff. The coarse grained sandstones were deposited in a braided river system, which during the Late Paleocene shed vast amounts of clastic sediments into the basinal areas south-east of the Kangerlussuaq region. The sediments are overlain by Paleocene hyaloclastites and columnar jointed basalts. Person for scale. sediments prograded from the western and north-western basin margin. These fluvial sediments are underlain by an erosional unconformity which is recognised throughout the region. The unconformity marks a change from a marine to a dominantly continental basin, and probably reflects regional uplift prior to and during initial volcanism in the Late Paleocene.

The lower lava series and the volcanoclastic rocks appear to be confined to local sedimentary basins showing strong thickness variations and diverging palaeocurrents. They consist of hyaloclastites, breccias, tuffs and tuffaceous sandstones of subaqueous origin (Nielsen et al., 1981). The volcanic activity continued into Eocene time, with the extrusion of a several kilometres thick continental plateau basalt succession over the entire region (see Brooks et al., this report). The region was exposed to regional uplift and erosion during the mid-Oligocene (Brooks \& Nielsen, 1982). 


\section{Future studies}

The 1995 field work will form the basis for detailed sedimentological and sequence stratigraphic studies, which have implications for interpretation of the development of the East Greenland continental margin. The ongoing work is coordinated with DLC studies in the Kangerlussuaq region on basin evolution, tectonics and early rifting both onshore and on the continental shelf offshore. Future work will be concentrated on geochemistry, palynology and 3-dimensional description of sandstone bodies in a Lower Cretaceous reservoir-analogue measured during the 1995 field work. The section is superbly exposed and further studies on geometry and sedimentary structures based on multimodel stereographic profiles are planned.

Acknowledgements. The project was financially supported by the Danish Lithosphere Centre (DLC), SAGA Petroleum a.s. and Danish Oil and Gas Production A/S (DOPAS) on behalf of the Amarada Hess Faeroe Islands Group. It forms part of the project 'Resources of the sedimentary basins of North and East Greenland' supported by the Danish Research Councils.

\section{References}

Brooks, C. K. \& Nielsen, T. D. F. 1982: The Phanerozoic development of the Kangerdlugssuaq area, East Greenland. Meddr Grønland, Geosci. 9, 31 pp.

Hamberg, L. 1990: The pre-basaltic upper Cretaceous - Tertiary sediments of the Kangerdlugssuaq area: evidence of submarine syn-rift deposits. In Brooks, C. K. (ed.) Kangerdlugssuaq studies: processes at a continental rifted margin, 46-55. Proceedings from meeting 24 . January 1990 . Copenhagen: Geological Institute.

Higgins, A. C., \& Soper, N. J. 1981: Cretaceous - Palaeogene subbasaltic and intrabasaltic sediments of the Kangerdlugssuaq area, central East Greenland. Geol. Mag. 118, 337-448.

Hinz, K., Eldholm, O., Block, M. \& Skogseid, J. 1993: Evolution of North Atlantic volcanic continental margins. In Parker, J. R. (ed.) Petroleum geology of Northwest Europe: Proceedings of the 4th conference, 901-913. London: Geological Society.

Mitchell, S. M., Beamish, G. W. J., Wood, M. V., Malacek, S. J., Armentrout, J. A., Damuth, J. E. \& Olson, H. C. 1993: Paleogene sequence stratigraphic framework of the Faeroe Basin. In Parker, J. R. (ed.) Petroleum geology of Northwest Europe: Proceedings of the 4th conference, 1011-1023. London: Geological Society.
Myhre, A. M., Eldholm, O., Faleide, J. I., Skogseid, J., Gudlaugsson, S. T., Planke, S., Stuevold, L. M. \& Vågnes, E. 1992: Norway-Svalbard Margin: Structural and stratigraphical styles. In Poag, C. W. and De Graciansky, P. C. (ed.) Geologic evolution of Atlantic continental rises, 157-185. New York: Van Nostrand Reinhold.

Nielsen, T. D. F., Soper, N. J., Brooks, C. K., Faller, A. M., Higgins, A. C., \& Matthews, D. W. 1981: The pre-basaltic sediments and the Lower Lavas at Kangerdlugssuaq, East Greenland. Their stratigraphy, lithology, palaeomagnetism and petrology. Meddr Grønland, Geosci. 6, 25 pp.

Nørgaard-Pedersen, N. 1991: A sedimentological approach to the Paleocene coastal environments at Kulhøje, East Greenland. In Brooks, C. K. \& Stærmose, T. (ed.) Kangerdlugssuaq studies: Processes at a continental rifted margin $11,53-58$. Proceedings from meeting January 1991. Copenhagen: Geological Institute.

Nørgaard-Pedersen, N. 1992: Delta sequences and initial volcanism in the Paleocene Kangerdlugssuaq basin, East Greenland. In Brooks, C. K., Hoch, E. \& Brantsen, A. K. (ed.) Kangerdlugssuaq studies: Processes at a continental rifted margin III. 24-31. Proceedings from meeting May 1992. Copenhagen: Geological Institute.

Soper, N. J., Higgins, A. C, Matthews, D. W. \& Brown, P. E, 1976: Late Cretaceous - early Tertiary stratigraphy of the Kangerdlugssuaq area, East Greenland, and the age of the opening of the North-Atlantic. J. Geol. Soc. London 132, 85-104.

Wager, L. R. 1934: Geological investigations in East Greenland. Part I: General geology from Angmagsalik to Kap Dalton. Meddr Gronland 105(2), $46 \mathrm{pp}$.

Wager, L. R. 1947: Geological investigations in East Greenland. Part IV: The stratigraphy and tectonics of Knud Rasmussens Land and the Kangerdlugssuaq region. Meddr Grønland 134(5), $64 \mathrm{pp}$.

Wager, L. R. \& Deer, W. A. 1939: Geological investigations in East Greenland. Part III: The petrology of the Skaergaard intrusion, Kangerdlugssuaq, East Greenland. Meddr Grønland 105(4), 352 pp.

M. L. \& L. S., Geological Survey of Denmark and Greenland, Copenhagen

L. H., Danish Oil and Gas Production A/S, Agern Allé 24-26, DK-2970 Horsholm, Denmark

S. O., SAGA Petroleum a.s., P.O. Box 490, N-1301 Sandvika, Norway 